\title{
Melanoma-Associated Antigen 10
}

National Cancer Institute

\section{Source}

National Cancer Institute. Melanoma-Associated Antigen 10. NCI Thesaurus. Code C104498.

Melanoma-associated antigen 10 (369 aa, $\sim 41 \mathrm{kDa}$ ) is encoded by the human MAGEA10 gene. This protein may be involved in tumor progression. 